\title{
International Demand Spillovers in South-South Exports: Application to Sub-Saharan Africa and Developing Asia
}

\author{
Thi Anh-Dao Tran \\ CREAM, University of Rouen \\ Diadié Diaw \\ CREAM, University of Rouen \\ Arsène Rieber \\ CREAM, University of Rouen
}

\begin{abstract}
This paper aims at analyzing how export performance of developing countries differs across destinations. With application to Sub-Saharan Africa and Asia, we first employ a gravity equation to break down each region's export performance, separating the contribution of foreign market access from internal supply capacity. Then, we identify the key determinants of countries' export performance, both theoretically and empirically. Our contribution is to introduce demand spillovers that help market access to improve supply conditions. Regression reveals a positive interaction between the two components, with a higher elasticity of exports with respect to market access in the particular case of South-South trade flows.
\end{abstract}

JEL Classifications: F14, F15, O11, O57

Key Words: Internal Supply Capacity, Foreign Market Access, Demand Spillovers, SouthSouth Trade, Sub-Saharan Africa, Developing Asia

\footnotetext{
* Corresponding Author: Thi Anh-Dao Tran; French Institute of Research for Development, CREAM, University of Rouen, IRD Vietnam, Building 2G, Van Phuc Diplomatic Compound, 298 Kim Ma, Ba Dinh, Hanoi, Vietnam, Tel: +84(0)437346656, Fax: +33(0)232769663, Email: thianh-dao.tran@univ-rouen.fr, thianh-dao.tran@ird.fr;

Co-Author: Diadié Diaw; University of Rennes 2, Place du recteur Henri Le Moal, F-35043 Rennes Cedex, France, Tel: 0033(0)66263209,Email: diadie_diaw@yahoo.fr,diadie.diaw@univ-rouen.fr;

Arsène Rieber; Department of economics, CREAM, University of Rouen, 3, avenue Pasteur, F-76186 Rouen Cedex 1, France, Tel: +33 2 327697 86, Email: arsene.rieber@univ-rouen.fr.

Acknowledgements: The authors are grateful to the anonymous referee for his/her detailed and constructive comments. A previous version was presented at the international conferences "Vietnam and East Asian countries facing the world crisis" (Foreign Trade University, Hanoi, Vietnam, 15 December 2009) and "Global economic crisis: issues, lessons and roads to recovery" (National Economics University, Hanoi, Vietnam, 16 December 2009). We would like to thank the conference participants for their remarks. The usual disclaimers apply.
} 


\section{Introduction}

Since the end of the 1980s, governments in developing countries have encouraged exports in the belief that they contribute to improved economic performance and growth in the long run. In particular, exporting has been an important channel through which Asian countries have been able to accelerate their pace of growth and emerge as major international competitors. The economic performances of the Newly Industrializing Countries (NICs) of East Asia (Hong Kong, Taipei, Singapore, and the Republic of South Korea), then the Asian tigers (Indonesia, Malaysia, Philippines, and Thailand), and now the third wave of NICs (China, India, and Vietnam) have been attributed to their raising shares of world exports. While real exports of developing economies grew by a factor of 2.5 from 1995 to 2006 - accounting for 37 per cent of world exports in 2006 - Asia clearly dominated the picture (UNCTAD, 2008a).

As the participation of developing countries in world trade has dramatically increased in the last two decades, South-South trade — that is, trade among developing countries — has acquired a growing interest. According to UNCTAD's statistics, South-South merchandise trade made up only 17 per cent of world exports in 2006. From 1985 however, it grew on average at an impressive rate of 12.5 per cent a year, compared with 7 per cent for North-North trade and 9.8 per cent for North-South trade (OECD, 2006).

Two phenomena mainly explain this 'new geography of international trade': the rapid emergence of some developing economies and the deepening of regional integration. In particular, the increasing interest in economic cooperation among developing countries has been revived by the challenges posed by China and, to a lesser extent, India (Winters and Yusuf, 2007). Indeed, the fast growth of these two Asian giants could play the role of growth engine for the whole developing world through inter-regional trade development. Consistent with this argument, trade flows had increased significantly between the developing countries of Asia and Africa by the end of the 1990s (Broadman, 2007). While Africa's exports to Asia grew at 15 per cent during 1990-1995, the annual growth rate has reached 30 per cent each year since 2003. Furthermore, with 40 per cent and 9 per cent shares respectively in Africa's total exports to Asia today, China and India have overtaken Japan and South Korea as the most important markets for Africa's exports (Yoshino, 2008).

Although growing at a tremendous rate, South-South merchandise trade displays a significant geographical concentration in the developing countries of Asia. This 'hub-and-spoke' pattern can be explained not only by the economic size of Asia but also by its high degree of regional integration and active participation in global production-sharing schemes (UNCTAD, 2008b). In 2005, 51 per cent of the developing Asia's total exports went to the South - against 30 per cent and 27 per cent for developing countries in Africa and Americas, respectively. However, the bulk of this South-South trade occurs among developing countries within a specific region: in 2005, intra-Asian South-South exports accounted for over 90 per cent of its total 
South-South exports. In contrast, Asia represents the most important destination for Africa's South-South exports.

Trade between the developing countries of Africa and Asia clearly presents an example of interregional specialization driven by factor endowments. Africa imports a wide range of manufactures from developing Asia, while the bulk of its exports are natural resources - including oil, mineral ores, and base metal products — and resource-based commodities. However, high value-added products, though still in their infancy, have also been increasing rapidly in popularity, especially in recent years (Yoshino, 2008).

While this interregional specialization following the theory of comparative advantage provides a simple but intuitive framework, there is an optimistic view that with greater trade with Asia, African countries have the potential to diversify their exports. The trend toward vertical integration and specialization has created numerous opportunities for countries with either low labour costs or with abundant natural resources to further expand their production. In addition, Asian dynamism has been accompanied by demand growth within the region, which in turn has created a favourable environment for a multiplier effect on the other developing regions. According to UNCTAD (2008b), over 20 per cent of the increase in trade between Africa and Asia during the period 1995-2005 was due to new trade relationships. By virtue of this argument, dynamic expansion in South-South trade reflects not only an increase in trade between traditional partner countries but also new trading patterns between countries that have never traded before.

Given this rapid pace of change in trade geography, our paper aims at exploring whether there are any differences in countries' export performance on global markets and on Southern markets. To do this, we focus on Sub-Saharan Africa (SSA) and Developing Asia (DA) for the period before the global financial crisis.

From a theoretical point of view, the study is grounded in models of international trade with product differentiation and trade costs under which geography may influence export performance (Krugman and Venables, 1995). On the one hand, a country's proximity to rapidly growing export markets will benefit from international demand linkages and thereby improve its export performance through a pecuniary demand effect across countries. This 'external geography' enables us to shed light on import demand constraints to explain the weak export growth registered by some developing countries. Conversely, many countries may benefit more than others from the export opportunities facilitated by their geographical location relative to sources of import demand. For instance, the countries of East and South-East Asia clearly illustrate such spillover effects between exporters when they are located in a fast growing region. On the other hand, a country's export potential may depend on 'internal geography,' such as physical infrastructure and access to ports, that influences supply-side conditions.

Our empirical investigation builds on Redding and Venables (2003, 2004a), who examined the determinants of countries' export performance by developing a helpful analytical model. In particular, gravity techniques are used to estimate the model's parameters and to break down a 
country's export growth into two parts: a 'Foreign Market Access' (FMA) component which measures the country's export growth due to changes in import demand from other countries, and a 'Supply Capacity' (SC) component which reflects internal contributions to export growth. Relying on this seminal work, Fugazza (2004) adopted the same empirical strategy to identify the determinants of export performance for a sample of 84 heterogeneous countries over the period 1980-1999. Similarly, Mayer (2008), Hering and Poncet (2010), and Fally et al. (2010) used an extension of Redding and Venables (2004b) to depict how market potential is a powerful driver of increases in per capita income and average wages.

Complementing previous works, our contribution is twofold. First, most studies on Asia and Africa focus on their export competition in third world markets without dealing with their growing interregional trade flows (Jenkins and Edwards, 2005; Stevens and Kennan, 2006; Kaplinski and Morris, 2008). Instead of exploring the issue of export rivalry between the emerging Asian countries and the rest of the developing world, the present paper seeks to understand how the former may contribute to improve export performance of the latter. Our study addresses the issue by using annual data on bilateral trade from 1992 to 2006 and by considering exports to the entire world and to developing countries.

Secondly, we extend the analytical model proposed by Redding and Venables (2004a) to examine the presence of demand spillovers forming from market access. As noted by Elbadawi et al. (2006), existing estimates of the determinants of Africa's export performance lack a tradetheoretic foundation. By formalizing a positive interaction between market access and domestic supply capacity, our theoretical background belongs to a long tradition in development economics that emphasizes how demand linkages may stimulate economic growth through pecuniary externalities.

The present paper will be divided into two parts. We first break down overall export performance by country and region, identifying the respective contribution of FMA and internal SC. Our second objective is to identify the main determinants of countries' export performance and to characterize them in the specific case of South-South trade flows. More precisely, we will determine how access to foreign markets and the development of domestic productive capacities interact with one another. This final step is of great interest for developing countries in light of the growing South-South trade integration.

The rest of the paper is organized as follows: Section 2 presents the estimation strategy and reports the breakdown of export performance. Section 3 constructs the final step and investigates the role of FMA and SC interaction in determining export performance. Section 4 concludes and presents some policy recommendations. 


\section{Export Growth Breakdown}

\section{A. Method and Data Sources}

Our main purpose here is to identify how demand and supply conditions are important in explaining countries' differences in export performance; the former refers to external factors, whereas the latter refers to internal conditions. This requires taking into account importing and exporting country characteristics and external elements influencing bilateral trade.

Relying on Redding and Venables (2003, 2004a), the theoretical model of international trade that specifies such breakdowns is developed in Appendix 1 . The value of total exports of country $i$ to country $j\left(V_{i j}\right)$ can be expressed as the product of its supply capacity $\left(S C_{i}\right)$ and country $j$ market capacity $\left(A_{j}\right)$ weighted by a measure of bilateral transaction costs between them $\left(T_{i j}\right)$ :

$$
V_{i j}=S C_{i} \cdot T_{i j}^{1-\sigma} A_{j}
$$

where $\sigma>1$ is the elasticity of substitution between any pair of products. By considering the value of its exports to all destinations, country $i$ 's overall export performance $\left(V_{i}\right)$ can then be broken down between supply capacity $\left(S C_{i}\right)$ and foreign market access $\left(M_{i}\right)$ : $V_{i}=\sum_{j \neq i} V_{i j}=S C_{i} \cdot M_{i}$ where $\mathrm{M}_{i}=\sum_{j \neq i} T_{i j}^{1-\sigma} A_{j}$ is a weighted sum of the market capacities of all other countries $j$.

Empirically, the usual way of bringing together all the bilateral trade information in relation (1) is with the use of gravity estimation ${ }^{1}$. To obtain measures of bilateral transaction costs, we use geographical distance and a dummy for whether two countries share a common border: $T_{i j}^{1-\sigma}=$ dist $_{i j}^{\alpha} \exp \left(\beta\left(\right.\right.$ Border $\left.\left._{i j}\right)\right)$ where dist $_{i j}$ is the bilateral distance between a pair of countries $\mathrm{i}$ and $\mathrm{j}$, and Border $_{i j}$ is a dummy variable that takes a value of one if the two countries share a common border and zero otherwise.

The gravity equation can then be written under a log-linear form as follows:

$$
\ln \left(V_{i j}\right)=\lambda_{j}\left(\operatorname{Pimp}_{j}\right)+\gamma_{i}\left(\text { Pex }_{i}\right)+\alpha \ln \left(\text { dist }_{i j}\right)+\beta\left(\text { Border }_{i j}\right)+\varepsilon_{i j}
$$

where $\lambda, \gamma^{\mathrm{i}}, \alpha, \beta$ are the estimated parameters and is the error term. We use the methodological approach adopted by Redding and Venables (2004b), which consists of introducing exportercountry and importer-partner dummies - respectively $\operatorname{Pex}_{i}$ and $\mathrm{Pimp}_{j}$ - to control for supplier capacity and market capacity. The supply capacity of the exporting country — measured

\footnotetext{
The gravity equation can be derived from many different trade models: those based on Dixit-Stiglitz monopolistic competition and product differentiation, but also on Heckscher-Ohlin (Deardorff, 1998; Evenett and Keller, 2002) or Ricardian trade frameworks (Eaton and Kortum, 2002). A more recent wave of theoretical contributions on gravity relies on models of international trade with firm heterogeneity (Chaney, 2008).
} 
by the dummy $P e x_{i}$ - will capture all observed and unobserved characteristics that affect its bilateral trade with all importers. Similarly, the market capacity of the importing country measured by the dummy $\operatorname{Pimp}_{j}$ — will capture those which affect its bilateral trade with all exporters ${ }^{2}$.

By virtue of this, we can then break down each country's export performance. For the supply capacity, we obtain:

$$
S C_{i}=\exp \left(\gamma_{i}\right)
$$

Foreign market access is derived from:

$$
M_{i}=\sum_{i \neq j} \exp \left(\lambda_{j}\right) \operatorname{dist}_{i j}^{\alpha} \exp \left(\beta\left(\text { Border }_{i j}\right)\right)
$$

In contrast to Redding and Venables (2004b), who built data series on a large cross-section of exporting countries, we limit our study to explore the export performance of Southern countries. By doing so, we apply the gravity model to a relatively homogeneous sample and overcome the methodological limitations of the sample including both developed and developing countries (Fontagné, et al., 2002). This is of great importance here as we will use the FMA predicted by the gravity estimation to investigate the determinants of export performance in a second step. Therefore, the empirical study is made on the value of bilateral trade flows for 54 Southern exporting countries - 38 from Sub-Saharan Africa and 16 from Developing Asia with a world importing group composed of 175 countries.

Trade data are computed from the United Nations Commodity Trade database (UN COMTRADE) at the one-digit SITC-2 products classification. Further details are given in Appendix 2. It is generally argued that trade data are of better quality when collected from the importing country's information (Fontagné et al., 2002). Hence, our bilateral trade data are collected giving priority to importing country information. The main difficulty in such an exercise is the distinction between zero bilateral flows and missing values. Therefore, we use the "mirror flows" technique to reduce missing values. Mirror flows are used to complete the trade dataset when the importing country has not reported a trade flow but that flow does exist when looking at the exporting country's information. After having used this technique, all bilateral cases of the export matrix, where there is no information from either country, are considered as zero trade flows. Trade data are then deflated by the United States GDP deflator — base year 1990 — to obtain real values of trade flows.

\footnotetext{
${ }^{2}$ An alternative approach was used by the same authors in Redding and Venables (2003, 2004a). Instead of measuring supply capacity and foreign market access by the exporter country and the importer partner dummies obtained from the gravity equation, they solved a system of equations for all countries' imports and exports in which the measures of SC and FMA are analytically determined from estimated trade costs. The disadvantage of this approach is that it does not directly use the estimates constructed from bilateral trade flows. However, the authors argue that in practice, there is a high degree of correlation between the two measures of SC and FMA.
} 
In addition, possible correlations between bilateral trade flow measurement errors and the volume of trade may exist. To account for this, observations are weighted by the product of exporter country and partner GDP, resulting in the use of Weighted Least Squares as a technique estimation tool ${ }^{3}$.

This study is conducted regardless of short-run determinants of export performance. Thus, given the high year-to-year fluctuation in bilateral trade flows, we divide the period 1992-2006 into five sub-periods of three years, and for each sub-period trade flows are averaged.

Finally, we also present a brief exploration of the importance of region-specific trade frictions by allowing the costs of trading within a region to differ from those of trading between regions. To allow trade costs to vary in this way, we augment the distance and border effects with intraregional trade dummies for whether two countries lie within the same geographical region.

\section{B. Estimation of Bilateral Trade Equations}

The results of estimating the gravity equation (2) are summarized in Table $1^{4}$. As expected, the coefficient on distance and the one on border (both are assumed to capture geographical bilateral transaction costs) are assigned accordingly with theoretical predictions. Notably, the farther away two countries are from each other, the higher their bilateral trade costs are and the less they would tend to trade. By the same token, two countries with a common border increase their tendency to trade.

\footnotetext{
${ }^{3}$ Due to problems of heteroskedasticity in OLS estimations, Pindyck and Rubinfeld (1998) suggest the use of Weighted Least Squares (WLS) estimation technique, which better fits the observations.

${ }^{4}$ To test for the robustness of our main results, we did some sensitivity analyses on the zero trade flows and on the sample selection bias. The results are not reported in this paper, but in both cases we found that the estimations are not significantly influenced.
} 
Table 1. Bilateral Trade Equation Estimation

Dependent Variable: $\operatorname{Ln}($ Export +1$)$

\begin{tabular}{|c|c|c|c|c|c|}
\hline Independent Variables & 1992 1994 & $1995 \sim 1997$ & $1998 \sim 2000$ & 2001 2003 & $2004 \sim 2006$ \\
\hline Ln(distance) & $\begin{array}{r}-1.11 * * * \\
(0.08)\end{array}$ & $\begin{array}{r}-1.48 * * * \\
(0.08)\end{array}$ & $\begin{array}{r}-1.29 * * * \\
(0.09)\end{array}$ & $\begin{array}{r}-1.31 * * * \\
(0.09)\end{array}$ & $\begin{array}{r}-1.36 * * * \\
(0.09)\end{array}$ \\
\hline Border & $\begin{array}{r}1.41^{* * * *} \\
(0.29)\end{array}$ & $\begin{array}{r}2.04 * * * \\
(0.23) \\
\end{array}$ & $\begin{array}{r}2.11 * * * \\
0.23) \\
\end{array}$ & $\begin{array}{r}2.02 * * * \\
(0.23) \\
\end{array}$ & $\begin{array}{r}2.23 * * * * \\
(0.26) \\
\end{array}$ \\
\hline Within SSA & $\begin{array}{l}-0.27^{*} \\
(0.15) \\
\end{array}$ & $\begin{array}{r}0.59^{* * * *} \\
(0.14) \\
\end{array}$ & $\begin{array}{r}0.85^{* * * *} \\
(0.14)\end{array}$ & $\begin{array}{r}0.84 * * * \\
(0.13)\end{array}$ & $\begin{array}{r}0.72 * * * \\
(0.14)\end{array}$ \\
\hline Within DA & $\begin{array}{l}-0.23 \\
(0.23)\end{array}$ & $\begin{array}{r}-1.18 * * * \\
(0.24)\end{array}$ & $\begin{array}{r}-0.90 * * * \\
(0.22)\end{array}$ & $\begin{array}{r}-1.25 * * * \\
(0.22)\end{array}$ & $\begin{array}{r}-1.54 * * * \\
(0.23)\end{array}$ \\
\hline Country Dummy & Yes & Yes & Yes & Yes & Yes \\
\hline Partner Dummy & Yes & Yes & Yes & Yes & Yes \\
\hline Number of observations & 9396 & 9396 & 9396 & 9396 & 9396 \\
\hline$F(232,9164)$ & 303.73 & 459.57 & 568.59 & 646.07 & 652.24 \\
\hline Prob $>F$ & 0.00 & 0.00 & 0.00 & 0.00 & 0.00 \\
\hline$R$-squared & 0.86 & 0.89 & 0.90 & 0.91 & 0.91 \\
\hline Root MSE & 2.45 & 2.41 & 2.36 & 2.29 & 2.34 \\
\hline
\end{tabular}

Note: Heteroscedasticity robust standard errors are in parenthesis. Significance level: ***(1\%), **(5\%), *(10\%). We use Ln (Exports +1$)$ to account for any zero value for the dependent variable

In addition to distance and border effects, coefficients on within-region dummies reflect the effect of any element that facilitates trade within the region. In the first sub-period, we can see that the coefficient on within SSA is negative and then becomes positive over the 1995-2006 period with statistical significance at the one percent level. Our result is consistent with Fugazza (2004), who conducted the same estimation: He found large negative coefficients on the intraSSA dummy from 1980 to 1995 , but it turned out to be positive for the last sub-period, 199699. The positive coefficients might reflect the fact that trade within the region has been eased compared to conditions prevailing in the 1980 s, either by an improvement in trade facilitation for the whole region or by trade intensification at a sub-regional level. This trend could indicate that trade in SSA has become more sub-region specific than region specific.

In contrast, the coefficient on the intra-DA dummy is negative for the all sub-periods considered and tends to increase. But as suggested by Fugazza (2004) and Redding and Venables (2003), the negative coefficients rather reflect the impact of growing bilateral trade with partners outside the region, notably following the financial crisis that hit the East Asian area in 1998. So, this tendency is likely to capture a process of outward-looking trade observed for the developing countries of Asia, but out of the region. 


\section{Foreign Market Access and Supply Capacity}

The measures of bilateral transaction costs derived above permit us to break down each country's export performance into the contributions of SC and FMA. The tables in Appendix 3 report the breakdown for individual countries of SSA and DA: here, we rely on Table 2 to examine the regional aggregates ${ }^{5}$.

Table 2. Components of Export Growth

\begin{tabular}{|c|c|c|c|c|}
\hline \multirow{2}{*}{ Region } & Period & $\begin{array}{c}\text { Export } \\
\text { growth (\%) }\end{array}$ & $\begin{array}{c}\text { Supply Capacity } \\
\text { growth (\%) }\end{array}$ & $\begin{array}{c}\text { Foreign Market } \\
\text { Access growth (\%) }\end{array}$ \\
\hline \multirow{4}{*}{$\begin{array}{c}\text { Sub-Saharan Africa } \\
\rightarrow \text { World }\end{array}$} & $\mathbf{9 2 / 9 4 \sim 0 4 / 0 6}$ & $\mathbf{1 3 0 . 5}$ & $\mathbf{2 4 7 . 6}$ & $\mathbf{- 3 8 . 2}$ \\
\cline { 2 - 5 } & $92 / 94 \sim 95 / 97$ & 78.6 & 117.2 & -20.4 \\
\cline { 2 - 5 } & $95 / 97 \sim 98 / 00$ & 1.0 & 15.1 & -15.4 \\
\cline { 2 - 5 } & $98 / 00 \sim 01 / 03$ & -14.9 & 2.0 & -12.2 \\
\cline { 2 - 5 } & $01 / 03 \sim 04 / 06$ & 50.2 & 36.3 & 4.5 \\
\hline \multirow{4}{*}{$\begin{array}{c}\text { Developing Asia } \\
\rightarrow \text { World }\end{array}$} & $\mathbf{9 2 / 9 4 \sim 0 4 / 0 6}$ & $\mathbf{5 8 8 . 4}$ & $\mathbf{5 1 6 . 7}$ & $\mathbf{8 4 . 4}$ \\
\cline { 2 - 5 } & $92 / 94 \sim 95 / 97$ & 81.9 & 71.7 & 31.6 \\
\cline { 2 - 5 } & $95 / 97 \sim 98 / 00$ & 13.3 & 26.5 & -13.1 \\
\cline { 2 - 5 } & $98 / 00 \sim 01 / 03$ & 22.3 & 32.8 & -1.2 \\
\cline { 2 - 5 } & $01 / 03 \sim 04 / 06$ & 173.3 & 113.9 & 63.4 \\
\hline
\end{tabular}

The first rows for SSA and DA present the growth rates of exports, SC, and FMA respectively for each region over the whole period considered. The results indicate that DA enjoyed outstanding export growth (588.4 per cent), nearly 90 per cent of which was driven by SC growth. A vast amount of literature on the first-tier NICs has assessed causes of the 'East Asian Miracle' and discussed extensively the lessons from it. Notably, some measures of industrial and trade policies were relevant to encourage diversification of exports and the expansion of domestic productive capacities in new manufactures (Nelson and Pack, 1999; Stiglitz and Yusuf, 2001; Wade, 1990; Weiss, 2005). As implied by the 'flying geese' pattern, the second-tier NICs - Indonesia, Malaysia, Philippines, and Thailand - also experienced rapid growth in the 1980s, followed in the 1990s by China, and then Vietnam.

Looking at individual countries' breakdown of export growth (Appendix 3), the Asian latecomers experienced a dramatic increase in SC growth in the early period - Vietnam, Indonesia, and Philippines. However, only China regularly improved its own-country capacity

\footnotetext{
${ }^{5}$ Recall that the rates of growth of SC and FMA compound to the rates of growth of total exports at the country level. But when we aggregate at the regional level, their product does not exactly correspond to the aggregated exports, so that the breakdown is approximate. $\sum_{i} V_{i}=\sum_{i} S C_{i} M_{i} \neq \sum_{i} S C_{i} \sum_{i} M_{i}$
} 
across sub-periods, achieving the highest SC growth in the last sub-period. In contrast, Vietnam started from the highest contribution of SC to export growth among DA but experienced a regular decline afterwards, although it ranked second within the region in the last sub-period. Nevertheless, the country is the highest exporter for all of the sub-periods considered, notably due to growing access to foreign markets in the final years of the period. Similarly, high export growth with an upward shift in FMA attests to the rapid integration of the Southern Asian countries - Pakistan, India, and Nepal — in the multilateral trade system since the beginning of the new millennium.

Unsurprisingly, SSA countries experienced a much slower export growth (130.5 per cent compared to 588.4 per cent). Despite this divergent performance however, our breakdown results reveal that the major engine of export growth was SC growth, to a larger extent than in DA. Moreover, such an improved own-country capacity over the period 1992-2006 offset a negative contribution of external markets (-38.2 per cent), even though we observed a downward trend for the latter. This is in sharp contrast to the early period before the 1990s, when heavy supply constraints explained weak export performance in the region (Redding and Venables, 2004a).

The relative contribution of external and internal components of export growth is more differentiated at the country level. Appendix 3 shows that the Ivory Coast experienced the best export performance driven by the highest SC growth in the first sub-period. But Senegal subsequently replaced the Ivory Coast in the last sub-period. In contrast, Burkina Faso, Togo, Tanzania, and Zimbabwe suffered from a downward trend for SC growth: this is particularly true for Zimbabwe, where the fall in SC worsened in the period covered. Seychelles is the most consistent country within the region, as the growth rates of exports, FMA, and SC regularly improved.

\section{The Interaction between Supply Capacity and Market Access}

Having separated out the FMA and internal SC contributions to export growth, our final stage of analysis consists of identifying the main determinants of each country's export performance. We focus more precisely on the interaction between FMA and the development of SC as we expect that, in equilibrium, the former is one of the variables that influences the return of exporting. In addition, we will determine how access to foreign markets and domestic productive capacities may interact differently across destinations. Do South-South bilateral trade flows influence export performance in a particular way? To conduct this analysis, we need to develop a theoretical framework in general equilibrium that will provide the impetus for our econometric estimation. 


\section{A. The Theoretical Background}

Redding and Venables (2004a) proposed a theoretical model to show how a country's internal supply capacity depends on its foreign market access. In order to make such a relationship evident, they consider the existence of a production possibility frontier between the export sector and other sectors of the economy. A better access to foreign markets is expected to expand the export sector, thereby increasing the demand for production factors. This pressure on the factor markets tends to bid up their costs, resulting in higher producer prices in the export sector, a loss in export competitiveness, and lower productive capacities. As a result, an increase in FMA will raise exports by a less than proportionate amount as SC is reduced.

However, this negative interaction between SC and FMA can be questioned if we introduce other transmission channels through which better access to foreign markets may impact domestic productive capacities in the export sector. Feder (1983) pioneered research in this field by accounting for inter-sectoral positive externalities generated by exports in a growth model with two sectors - one non-export sector and one export sector. Esfahani (1991) followed by arguing that export expansion helps to relax foreign currency constraints on imports that are required for production. More recently, export spillovers have been developed in models of international trade: for example, firms that penetrate foreign markets reduce entry costs for other potential exporters due to learning effects or commercial linkages (Aitken, et al. 1997).

These kind of trade or growth theories concentrate mostly on the supply side. However, there is a long tradition in development economics that emphasizes how demand linkages may stimulate economic growth through pecuniary externalities linked to increased returns to scale. In the late 1980s, Shleifer and Vishny (1988) developed a model with aggregate demand spillovers in which there are multipliers that are ignored by firms making investment decisions. In the same vein, Murphy et al. (1989a) formalized industrial modernization as the outcome of coordinated investments which propagate increasing returns across industries. In their second paper, pecuniary externalities function through the buying power of the middle class, which may determine the extent of horizontal complementarity across industries (Murphy et al. 1989b). Relying on these kind of studies, Desdoigt and Jaramillo (2009) investigated how the emergence of a global middle class may influence trade flows and the pattern of global production. They focus on international demand spillovers that contribute to expand production and achieve increasing returns to scale, giving rise to a global profit-multiplier process. The magnitude and direction of these international demand spillovers determine the importance of the cumulative process in each country.

More generally, recent literature has pointed out the importance of demand-side factors within models of international trade. For instance, some contributions showed that, under the assumption of non-homothetic preferences, income distribution becomes a determinant of aggregate demand and therefore of trade flows (Fajgelbaum, et al., 2011a; Follmi et al., 2010; 
Mitra and Trindade, 2005) ${ }^{6}$. This literature augments another study which follows the long line of post-Keynesian economics to explore demand effects in the light of growth theory. Opposite to the neoclassical growth model, this alternative approach postulates that overall growth of an open economy is mainly constrained by the external balance, and it emphasizes the role of demand as the driving force for domestic growth (Thirlwall, 2002). Interestingly, Aoki and Yoshikawa (2002) present a model suggesting that 'saturation of demand' for an individual good/ sector is another important factor restraining growth. In the context of demand constraints, innovation or technical progress creates a major new product or industry which commands high demand and sustains economic growth.

In line with this literature, we assume the presence of international demand spillovers which can, in fine, generate positive externalities on domestic productive capacities. These externalities may result from multiple sources, as suggested by the studies mentioned above; therefore, instead of focusing this analysis on one of them, we consider that access to foreign markets implies demand spillovers on aggregate. By virtue of this, our theoretical model allows for an indirect effect by market access on export performance. FMA with subsequent demand spillovers may favour the export sector by offsetting factor market pressures imposed by factor endowments, meaning that the status of the relationship between FMA and SC could be uncertain. If demand spillovers prevail, then FMA and SC will be positively correlated. This positive interaction will fuel a cumulative process such that better access to external markets will increase exports more than proportionately.

In the following analytical development, we propose to add some general features of equilibrium to the theoretical framework developed by Redding and Venables (2004a) in order to formalize two opposite effects: on the one hand, the tensions on the factor markets which induce a negative relationship between FMA and SC; and on the other hand, the demand spillovers which cause, inversely, a positive interaction between the two variables.

Using the trade model developed in Appendix 1, we define the quantity of exports demanded from country i as follows:

$$
n_{i} x_{i}=n_{i} p_{i}^{-\sigma} t_{i}^{1-\sigma} M_{i}
$$

where $n_{i}$ denotes the number of firms, $\sigma>1$ the elasticity of substitution between the differentiated goods, $x_{i}$ the output per firm, $p_{i}$ the price of the differentiated good, $t_{i}$ the internal transaction costs in country $i$, and $M_{i}$ the foreign market access of country $i$.

In addition, we specify a function $\Omega$ which describes the export supply:

$$
n_{i} x_{i}=a_{i} \Omega\left(\frac{p_{i}}{c_{i}} ; M_{i}\right) \text { with } \frac{\partial \Omega}{\partial\left(p_{i} / c_{i}\right)}>0 \text { and } \frac{\partial \Omega}{\partial M_{i}}>0
$$

\footnotetext{
${ }^{6}$ For an empirical contribution to this theoretical underpinning, see Dalgin, et al. (2008).
} 
Export supply depends on comparative costs in the export sector of country $i\left(c_{i}\right)$, on the price of exports $\left(p_{i}\right)$, and on the size of the country $\left(a_{i}\right)$. We illustrate the aforementioned argument relative to the opportunity cost of resources used in the export sector: expanding the quantity of exports increases their prices via tensions on the factor markets. The smaller the price elasticity of export supply (denoted $\omega$ thereafter), the tighter these tensions will become.

We complete the supply relationship by introducing demand spillovers created by access to international markets. The relation between SC and FMA is made endogenous by adding onto the right-hand side of equation (6) $M_{i}$, which has a positive effect on country $i$ 's export supply. This element highlights the importance of external demand as a determinant of internal capacities. Denoting $m$ as the elasticity of export supply with respect to $M_{i}$, we can assume that the stronger the demand spillovers, the higher $m$ will be.

By logarithmically differentiating relations (5) and (6) at equilibrium, we obtain:

$$
\begin{aligned}
& \hat{x}=-\sigma p+(1-\sigma) \hat{t}+\hat{M} \\
& \hat{n}+x=\hat{a}+\omega(p-c)+m \hat{M}
\end{aligned}
$$

where . denotes a proportional deviation from some reference point.

Solving this system will give the following variation in the total value of exports:

$$
\hat{V}=\hat{n}+p+\hat{x}=a-\hat{c} \omega+\frac{(\omega+1)}{\sigma}[(1-\sigma) \hat{t}-x]+\left(\frac{1+\omega}{\sigma}+m\right) M
$$

In a standard monopolistic competition model, output by a firm is constant at equilibrium, $\hat{x}=0$, so that (8) can be rewritten as follows:

$$
\hat{V}=\hat{a}-c \omega+\frac{(\omega+1)}{\sigma}(1-\sigma) \hat{t}+\left(\frac{1+\omega}{\sigma}+m\right) M
$$

The last equation will form the basis of our econometric investigation. Without ambiguity, we can see that internal transaction costs $(\hat{t})$ negatively impact export performance: by increasing the prices of goods produced in country $i$, a higher $t_{i}$ reduces the demand for exports by country $j$. Domestic size $(\hat{a})$ increases the value of exports while the comparative costs in the export sector $(\hat{c})$ have, logical ly, a negative impact.

The coefficient associated with $\hat{M}$ captures the status of the interaction between FMA and the country's SC. The estimated elasticity of export performance with respect to FMA $(\hat{M})$ will be less than one if the tensions on the factor markets outweigh the demand externalities. From an analytical viewpoint, the two opposite effects are analysed through a discussion on the parameters $\omega, \sigma$, and $m$ following the expression:

$$
\frac{\partial \hat{V}}{\partial \hat{M}}<1 \text { if and only if } \underbrace{\frac{1+\omega}{\sigma}}_{\text {tensions on the factor markets }}+\underbrace{m}_{\text {demand externalities }}<1 \text { and vice versa }
$$


If $\sigma>1$ is large relative to $\omega$ and $m$ is small enough, then FMA growth will imply a less than proportional growth in countries' exports because of tensions on the factor markets $\partial \hat{V} / \partial M<1$. In most Southern countries, assuming a high elasticity of substitution between two varieties of goods in export demand $(\sigma)$, a small price elasticity of export supply $(\omega)$ is selfevident. On the contrary, weak demand spillover effects associated with FMA $(m)$ are far less obvious. Rather, many recent studies argue that their magnitude can be differentiated along the foreign markets which Southern countries export to ${ }^{7}$.

\section{B. Estimations and Results}

Empirical specification of relation (9) will consist of estimating an equation where the dependent variable is the log of the value of exports $(\hat{V})$. The measure of FMA $(\hat{M})$ has been constructed from our previous breakdown. Country size $(\hat{a})$ is measured by the country's log of GDP and of population, and this is likely to reflect the size of its export sector. Comparative costs of exporting $(\hat{c})$ are captured by two indicators of institutional quality: trade openness (T-Freedom) and corruption alleviation (C-Freedom). For the internal transaction costs $(\hat{t})$, we use the percentage of paved roads present in total road networks (Rpaved), as it will reflect the quality of an economy's infrastructure. However, transaction costs are not only about the physical infrastructure for trade but also may range from preparing documentation to meet customs and insurance requirements to the time associated to the exporting procedures. According to Djankov et al. (2010), only about one quarter of the delays in export time is due to poor infrastructure. Therefore, we also use a new dataset on the average time it takes to trade products across borders $(T A B)$ in order to take into account larger aspects of internal transaction costs, including the inland transport of goods and utility connections for businesses. Finally, we include a regional dummy $\left(\mu_{k}\right)$ to control for unobserved heterogeneity across regions in the determinants of export performance (divergent institutions, technological features, etc.).

Thus, the estimation equation takes the form:

$$
\begin{aligned}
\operatorname{Ln}\left(V_{i}\right)= & \text { Cons }+\alpha \operatorname{Ln}\left(G D P_{i, t-1}\right)+\beta \operatorname{Ln}\left(P_{O} P_{i}\right)+\lambda \operatorname{Ln}\left(M_{i}\right)+\varphi \text { Rpaved }_{i}+\delta \text { TAB }_{i} \\
& +\phi \text { TFreedom }_{i}+\chi \text { CFreedom }_{i}+\mu_{k}+\varepsilon_{i}
\end{aligned}
$$

Sources of data on the variables are presented in Appendix 2. However, because institutional data are not available for all countries, we have reduced our sample to 45 Southern countries ${ }^{8}$.

\footnotetext{
${ }^{7}$ See mainly the economic literature about North-South versus South-South regional integration (Cernat, 2001; Puga and Venables, 1998; Schiff and Winters, 2004; World Bank, 2000).

${ }^{8}$ The following countries are excluded from the initial sample: Central African Republic, Mauritania, Mauritius, Seychelles, Somalia, Bhutan, Brunei Darussalam, Maldives, and Nepal.
} 
To account for possible endogeneity issues, GDP values are lagged by one period. Another problem is that the FMA measure results from the estimated coefficients from equation (2). So, the stochastic errors in the gravity equation turn up in FMA, affecting along the way the stochastic behaviour of the residual in equation (11). In this context, underlined assumptions of standard OLS estimations are violated, making necessary the use of a corrected estimator (Pagan, 1984). Therefore, we tackle this issue by using bootstrap techniques that take into account the parameter uncertainty ${ }^{9}$. Table 3 initially reports regression estimates for exports to the entire world.

Table 3. Determinants of Export Performance

Dependent Variable: Ln(Exports to the World)

\begin{tabular}{|c|c|c|c|c|}
\hline Independent Variables & $1995 \sim 1997$ & $1998 \sim 2000$ & $2001 \sim 2003$ & 2004 2006 \\
\hline \multirow[t]{2}{*}{$\operatorname{Ln}\left(G D P_{t-1}\right)$} & $0.941 * * *$ & $0.813 * * *$ & $0.744 * * *$ & $0.792 * * *$ \\
\hline & 0.22 & 0.26 & 0.32 & 0.33 \\
\hline \multirow[t]{2}{*}{$\operatorname{Ln}($ Pop $)$} & 0.255 & 0.411 & 0.472 & 0.450 \\
\hline & 0.23 & 0.28 & 0.32 & 0.36 \\
\hline \multirow[t]{2}{*}{$\operatorname{Ln}(M)$} & $0.792 * *$ & $0.693 * *$ & $0.644 * *$ & 0.510 \\
\hline & 0.34 & 0.35 & 0.30 & 0.37 \\
\hline \multirow[t]{2}{*}{ Rpaved } & $0.018 *$ & 0.014 & 0.009 & 0.006 \\
\hline & 0.01 & 0.01 & 0.01 & 0.01 \\
\hline \multirow[t]{2}{*}{$T A B$} & $-0.027 * *$ & $-0.032 * * *$ & $-0.038 * * *$ & $-0.041 * * *$ \\
\hline & 0.01 & 0.01 & 0.01 & 0.01 \\
\hline \multirow[t]{2}{*}{ T-Freedom } & 0.007 & 0.016 & 0.015 & 0.011 \\
\hline & 0.01 & 0.01 & 0.01 & 0.01 \\
\hline \multirow[t]{2}{*}{ C-Freedom } & 0.020 & $0.025 *$ & 0.022 & $0.023^{*}$ \\
\hline & 0.01 & 0.02 & 0.02 & 0.01 \\
\hline \multirow[t]{2}{*}{ Constant } & $-20.029 * * *$ & $-18.954 * * *$ & $-17.471 * * *$ & $-16.147 * * *$ \\
\hline & 5.63 & 5.47 & 5.59 & 5.67 \\
\hline Region effects & yes & yes & yes & yes \\
\hline Number of observations & 45 & 45 & 45 & 45 \\
\hline Chi2 & 708 & 677 & 825 & 532 \\
\hline Prob $>$ Chi 2 & 0.000 & 0.000 & 0.000 & 0.000 \\
\hline R-squared & 0.945 & 0.942 & 0.941 & 0.938 \\
\hline
\end{tabular}

Note: Bootstrap robust standard errors are in italics (200 replications). Significance level: ***(1\%), **(5\%), *(10\%).

\footnotetext{
${ }^{9}$ The conventional number of bootstrap replications used to estimate a standard error is $50-200$ (Efron and Tibshirani, 1993). So we report on 200 bootstrap replications in this paper.
} 
As expected, the GDP is highly significant with a positive sign, suggesting that export performance is positively related to the country size. But its coefficient is less than one, implying that larger countries export relatively less. In the same vein, we find a positive but insignificant effect for population. The presence in our sample of some large Asian countries, such as China, India, or Indonesia, may explain this result however.

Our empirical investigation also captures the controversial interaction between FMA and SC. The coefficient for FMA is significant in the first three sub-periods and strictly less than one, indicating that exports grow proportionally less than market access due to a lower increase in SC. This finding is in line with Redding and Venables (2004a) and implies that higher costs and prices in the export sector prevail over the demand spillovers when we consider access to all markets.

A measure of internal geography is captured by the percentage of paved roads in the country. This variable appears to be insignificant and may imperfectly reflect the internal transaction costs. We find rather that time delays $(T A B)$ negatively affect countries' exports; this implies that facilitating trade through time savings can have relatively larger effects on exports than domestic transport infrastructure does.

In contrast to standard predictions, we find that neither trade openness nor corruption alleviation is a relevant instrument in improving export performance. For developing countries, going through a trade openness program would not necessarily improve their external position. Consistent with former experiences in East Asia, countries like China and India have strongly improved their export performance while their trade regime continued to be very restrictive until the end of the 1990s (Rodriguez and Rodrick, 2001; Rodrick, 2006). By the same token, there is no evidence of a strong linkage describing a negative impact of corruption on countries' export performance. Consequently, trade liberalisation and better institutions through corruption alleviation are less likely to explain export performance than trade facilitation. 
Table 4. Determinants of South - South Export Performance

Dependent Variable: Ln(Exports to the World)

\begin{tabular}{|c|c|c|c|c|}
\hline Independent Variables & $1995 \sim 1997$ & $1998 \sim 2000$ & $2001 \sim 2003$ & $2004 \sim 2006$ \\
\hline \multirow[t]{2}{*}{$\operatorname{Ln}\left(G D P_{t-1}\right)$} & $0.924 * * *$ & $0.806 * * *$ & $0.747 * * *$ & $0.813 * *$ \\
\hline & 0.22 & 0.25 & 0.27 & 0.31 \\
\hline \multirow[t]{2}{*}{ LnPop } & 0.314 & $0.468^{*}$ & $0.505^{*}$ & 0.468 \\
\hline & 0.19 & 0.27 & 0.28 & 0.30 \\
\hline \multirow[t]{2}{*}{$L n M$} & $1.125 * * *$ & $1.098 * * *$ & $1.016 * * *$ & $0.905 * * *$ \\
\hline & 0.14 & 0.16 & 0.14 & 0.22 \\
\hline \multirow[t]{2}{*}{ Rpaved } & $0.020 * *$ & 0.015 & 0.009 & 0.006 \\
\hline & 0.01 & 0.01 & 0.01 & 0.01 \\
\hline \multirow[t]{2}{*}{$T A B$} & $-0.029 * * *$ & $-0.033 * * *$ & $-0.039 * * *$ & $-0.042 * * *$ \\
\hline & 0.01 & 0.01 & 0.01 & 0.01 \\
\hline \multirow[t]{2}{*}{ T-Freedom } & 0.007 & 0.015 & 0.015 & 0.013 \\
\hline & 0.01 & 0.01 & 0.01 & 0.01 \\
\hline \multirow[t]{2}{*}{ C-Freedom } & $0.024 *$ & $0.029 *$ & $0.024 *$ & $0.026^{*}$ \\
\hline & 0.01 & 0.02 & 0.01 & 0.01 \\
\hline \multirow[t]{2}{*}{ Constant } & $-24.209 * * *$ & $-24.146^{* * *}$ & $-22.280 * * *$ & $-21.725^{* * *}$ \\
\hline & 3.15 & 3.39 & 3.43 & 5.24 \\
\hline Region effects & yes & yes & yes & yes \\
\hline Number of observations & 45 & 45 & 45 & 45 \\
\hline$\chi^{2}$ & 1396 & 1173 & 944 & 1026 \\
\hline Prob $>\chi^{2}$ & 0.000 & 0.000 & 0.000 & 0.000 \\
\hline $\mathrm{R}^{2}$ & 0.962 & 0.956 & 0.952 & 0.950 \\
\hline
\end{tabular}

Note: Bootstrap robust standard errors are in italics (200 replications). Significance level: ***(1\%), **(5\%), *(10\%).

In a second step, we estimate relation (11) by restricting our investigation to Southern destinations: that is, SSA exports to DA and vice versa (Table 4). Globally, regression estimates are both in line with initial results for the entire world, except for the coefficient for FMA: the latter is particularly high and significant in all the sub-periods when we consider South-South exports only. This seems symptomatic of a positive interaction between FMA and SC.

Looking at our theoretical discussion, one explanation is that the parameter $\mathrm{m}$ depends on the importing partners whereas $\omega$, which measures the price elasticity of export supply, is specific to the exporter's SC. The latter is independent from foreign markets and in fact captures the tensions on domestic factor markets. Comparing Tables 3 and 4, we can deduce that the demand spillovers are drastically reinforced in the specific case of South-South bilateral trade flows: this is especially evident in the first three sub-periods, where the coefficient for FMA 
growth is greater than one. In the latter cases, access to Southern markets induces a multiplier effect on the country's export performance. Our result attests to the role of the developing countries of Asia as growth engines and the relevance for SSA countries of facilitating SouthSouth trade to foster export development ${ }^{10}$. Even a slight easing of market access conditions among SSA countries under inter-regional or bilateral trade arrangements could provide a sustained improvement in their export performance.

In addition, it is worth noting that $C$-Freedom becomes more significant in the specific case of South-South trade combinations. This means that better institutions through corruption alleviation are likely to be key elements for South-South exporting.

\section{Conclusion}

As the participation of developing countries in world trade has increased in recent decades, South-South trade integration has gained growing interest, due notably to an era of globalization driven by China and India. The growth dynamics of these two Asian giants have substantially modified the economic prospects for other developing countries. Relying on recent trends in international trade, this paper has explored how demand and supply conditions are important in explaining countries' differences in export performance. In addition, do South-South trade combinations influence export development in a particular way? By investigating such issues, our study has aimed at determining policy implications in support of the South's ascent.

First, we used a gravity equation to develop a general breakdown of export performance into the contributions of FMA and SC. Our findings indicate that the developing countries of SSA and Asia have experienced a similar upward trend in their internal supply-side conditions since the early 1990s. Then, our second stage of analysis consisted of identifying the main determinants of each country's export performance. We focused in particular on the interaction between FMA and the development of SC and more deeply investigated this issue in the specific case of South-South trade combinations. From this perspective, we formalized the presence of demand spillovers: market access may interact positively with internal supply capacity through pecuniary externalities, thereby enhancing exports by a cumulative process which lies behind the divergent performances among developing countries. The relation between SC and FMA then becomes endogenous through two contradictory effects at work: on the one hand, the tensions on the domestic factor markets lower the level of SC with better FMA; but on the

\footnotetext{
${ }^{10}$ This result can be extended by taking into account Foreign Direct Investment (FDI). Relying on a model with consumers' nonhomothetic preferences for goods of different quality, Fajgelbaum et al. (2011b) recently showed that FDI is more likely to occur among countries that are at a similar stage of development. In other words, firms re-orientate their FDI flows disproportionately to countries with per capita income levels similar to their home market. In conjunction with the emerging South-South trade, this model enables us to understand the growing flows of South-South FDI.
} 
other hand, the resulting demand effects are favourable to internal SC.

Our results have major policy implications for developing countries seeking to expand their export capacities.

First, the study stresses the role played by the business environment and internal trade facilities in the case of South-South exports. Weak institutional capacities influence the export performance of developing countries, especially when they allow discretionary behaviour or corruption to arise. By the same token, trade infrastructure which reduces time costs is necessary for expanding exports.

Secondly, and most importantly, our analysis reveals the existence of interaction between FMA and SC and the extent to which it may alter export performance. The latter transmission channel depends on the importing partners: where South-South trade relations are concerned, the demand linkages favourable to internal SC counteract the negative effects of tensions on the factor markets, thereby inducing a spillover effect on export growth. This result shows the extent to which fast and sustained market access growth in the Asian developing area is beneficial to the SSA countries through pecuniary demands and reinforces their export performance. It suggests that developing countries should favour South-South trade integration, as enhancement of their productive capacities by demand spillovers are more important than in third markets. The 'new geography of international trade' stressed by UNCTAD is a relatively reassuring feature in the context of the current global crisis.

Trade patterns between SSA and DA are changing very rapidly, and there is certainly room for further research issues to be developed. More specifically, the existence of a positive relationship between SC and FMA has multiple sources and must receive special attention. Among our research perspectives, one of them would consist of differentiating the mechanisms through which the demand effects help market access to improve supply conditions.

Received 22 September 2011, Revised 06 June 2012, Accepted 21 June 2012

\section{References}

Aitken, B., G.H. Hanson, A.E. Harrison (1997), Spillovers, foreign investment, and export behaviour, Journal of International Economics, 43(1-2), 103-132, August.

Aoki, M., H. Yoshikawa (2002), Demand saturation-creation and economic growth, Journal of Economic Behaviour and Organization, 48(2), 127-154.

Broadman, H.G. (2007), Africa's Silk Road: China and India's New Economic Frontier, World Bank, Washington DC.

Cernat, L. (2001), Assessing Regional Trade Arrangements: Are South-South RTAs More Trade Diverting?, Policy Issues in International Trade and Commodities Study Series, 16, UNCTAD, United Nations, New-York and Geneva. 
Chaney, T. (2008) Distorted Gravity: the Intensive and Extensive Margins of International Trade, American Economic Review, 98(4), 1707-1721.

Dalgin, M., V. Trindade, D. Mitra (2008), Inequality, Nonhomothetic Preferences, and Trade: A Gravity Approach, Southern Economic Journal, 74(3), 747-774.

Deardorff A.V. (1998): Determinants of Bilateral Trade: Does Gravity Work in a Neoclassical World?, in The Regionalization of the World Economy, edited by J.A. Frankel, University of Chicago Press, Chicago, pp. 7-32.

Desdoigt, A., F. Jaramillo (2009), Trade, demand spillovers and industrialization: The emerging global middle class in perspective, Journal of International Economics, 79(2), 248-258.

Djankov, S., C. Freund, C.S. Pham (2010), Trading on time, Review of Economics and Statistics, 92(1), 166173, February.

Eaton, J. and S. Kortum (2002): Technology, Geography, and Trade, Econometrica, 70(5), p. 1741-1779.

Evenett S.J. and Keller W. (2002): On Theories Explaining the Success of the Gravity Equation, Journal of Political Economy, 110(2), p. 281-316.

Efron, B., R. Tibshirani (1993), An introduction to the bootstrap. Monographs on Statistics and Applied Probability, Chapman \& Hall, New York.

Elbadawi, I., T. Mengistae, A. Zeufack (2006), Market access, supplier access, and Africa's manufactured exports: A firm level analysis, Journal of International Trade and Economic Development, 15(4), 493-523.

Esfahani, H.S. (1991), Exports, imports, and economic growth in semi-industrialized countries, Journal of Development Economics, 35(1), 93-116, January.

Fajgelbaum P.D., G.M. Grossman, E. Helpman (2011a), Income distribution, product quality, and international trade, Journal of Political Economy, 119(4), 721-765.

Fajgelbaum P.D., G.M. Grossman, E. Helpman (2011b), A Linder Hypothesis for Foreign Direct Investment, NBER Working Paper, 17550.

Fally, T., R. Paillacar, C.. Terra (2010), Economic geography and wages in Brazil: Evidence from micro-data, Journal of Development Economics, 91(1), 155-168.

Feder, G. (1983), On exports and economic growth, Journal of Development Economics, 12(1-2), 59-73, February-April.

Follmi R., C. Hepenstrick, J. Zweimüller (2010), Non-homothetic preferences, parallel imports and the extensive margin of international trade, CEPR Discussion Papers, 7939.

Fontagné, L., M. Pajot, J.M. Pasteels (2002), Potentiels de commerce entre économies hétérogènes: un petit mode d'emploi des modèles de gravité, Economie et Prévision, 152-153, 115-139.

Fugazza, M. (2004), Export Performance and its Determinants: Supply and Demand Constraints, Policy Issues in International Trade and Commodities Study Series, 26, UNCTAD, United Nations, New-York and Geneva.

Hering, L., S. Poncet (2010), Market Access and Individual Wages: Evidence from China, Review of Economics and Statistics, 92(1), 145-159.

Jenkins, R., C. Edwards (2005), “The effect of China and India's growth and trade liberalisation on poverty in Africa". UK Department for International Development.

Kaplinsky, R., M. Morris (2008), Do the Asian drivers undermine export-oriented industrialization in SSA?, 
World Developmen, 36(2), 254-273, February.

Krugman, P., A.J. Venables (1995), Globalization and the Inequality of Nations, Quarterly Journal of Economics, 110(4), 857-880.

Mayer, T. (2008), Market Potential and Development, CEPR Discussion Paper, 6798.

Mitra D., V. Trindade (2005), Inequality and Trade, The Canadian Journal of Economics, 38(4), 1253-1271.

Murphy, K.M., A. Shleifer, R. Vishny (1989a), Industrialization and the Big Push, Journal of Political Econo$m y, 97(5), 1003-1026$.

Murphy, K.M., A. Shleifer, R. Vishny (1989b), Income distribution, market size, and industrialization, Quarterly Journal of Economics, 104(3), 537-564.

Nelson, R., H. Pack (1999), The Asian miracle and modern growth theory, Economic Journal 109(457), 41636 , July.

Organisation for Economic Cooperation and Development (2006), South-South Trade: Vital for Development, Policy Brief, August.

Pagan, A. (1984), Econometric issues in the analysis of regressions with generated regressors, International Economic Review, 25(1), 221-247.

Pindyck, R.S., D.L. Rubinfeld (1998), Econometric Models and Economic Forecasts, Irwin/McGraw-Hill, Boston MA.

Puga, D., A.J. Venables (1998), Trading Arrangements and Industrial Development, The World Bank Economic Review, 12(2), 221-249.

Redding, S., A.J. Venables (2003), South-East Asian export performance: external market access and internal supply capacity, Journal of the Japanese and International Economies, 17(4), 404-431.

Redding, S., A.J. Venables (2004a), Geography and Export Performance: External Market Access and Internal Supply Capacity, in Challenges to Globalization: Analyzing the Economics, edited by R. Baldwin and A. Winters, University of Chicago Press, Chicago, pp. 95-130.

Redding, S., A.J. Venables (2004b), Economic geography and International Inequality, Journal of international Economics, 62, 53-82.

Rodriguez, F., D. Rodrik (2001), Trade Policy and Economic Growth: A Skeptic's Guide to the Cross-National Evidence, in NBER Macroeconomics Annual 2000, edited by B. Bernanke and K.S. Rogoff, MIT Press, Cambridge MA, pp. 261-338.

Rodrik, D. (2006), Growth Strategies, in Handbook of Economic Growth, edited by P. Aghion and S. Durlauf, Elsevier, North-Holland, Amsterdam, vol. 1A, Chapter 14, pp. 967-1014.

Schiff, M., A.L. Winters (2004), Regional Integration and development, World Bank, Washington DC.

Shleifer, A., R.W. Vishny (1988), The efficiency of Investment in the Presence of Aggregate Demand Spillovers, Journal of Political Economy, 96(6), 1221-1231.

Stevens, C., J. Kennan (2006), How to identify the trade impact of China on small countries, IDS Bulletin, 37(1), 33-42. Brighton: Institute of Development Studies.

Stiglitz, J., S. Yusuf, ed. (2001), Rethinking the East Asian Miracle, Oxford University Press for the World Bank, New York. 
Thirwall, A.P. (2002), The Nature of Economic Growth. An Alternative Framework for understanding the Performance of Nations. Edward Elgar.

UNCTAD (2008a), Development and globalization: Facts and Figures 2008, United Nations, New-York and Geneva.

UNCTAD (2008b), South-South Trade in Asia: the Role of Regional Trade Agreements, United Nations and JETRO, New-York and Geneva.

Wade, R. (1990), Governing the market. Economic theory and the role of government in East Asian industrialization, Princeton University Press, New Jersey.

Weiss, J (2005), Export growth and industrial policy: lessons from the East Asian miracle experience, $A D B$ Institute Discussion Paper, 26, Asian Development Bank Institute, Tokyo, February.

Winters, A.L., S. Yusuf, ed. (2007), Dancing with Giants, World Bank and the Institute of Policies Studies, Washington DC.

World Bank (2000), Trade Blocs, Oxford University Press, New York.

Yoshino, Y. (2008), Africa-Asia Trade and Investment: Opportunities and Challenges, World Bank, Washington DC, April. 


\section{Appendices}

\section{Appendix 1: The Theoretical Framework (Redding and Venables, 2004a)}

The theoretical framework is essentially a standard monopolistic competition model of international trade in the presence of product differentiation and trade costs. Let us consider a world composed of $\mathrm{N}$ countries producing a range of differentiated products. The demand for differentiated products is modelled using a symmetric Constant Elasticity of Substitution (CES) in the utility function as follows:

$$
U_{j}=\left[\sum_{i=1}^{N} n_{i} x_{i j}^{(\sigma-1) / \sigma}\right]^{\sigma /(\sigma-1)}, \sigma>1
$$

where $\sigma$ is the elasticity of substitution between any pair of products, $n_{i}$ is the set of varieties produced in country $i$, and $x_{i j}$ is the consumption by country $j$ of a single product variety from this set.

Using the product symmetry hypothesis, we can then define the price index in each country $j\left(G_{j}\right)$ by using the price of individual varieties produced by country $i$ and sold in country $j\left(p_{i j}\right)$ :

$$
G_{j}=\left[\sum_{i=1}^{N} n_{i} p_{i j}^{1-\sigma}\right]^{1 / 1-\sigma}
$$

Let's denote $E_{j}$ as country $j$ 's total expenditure on industrial differentiated products. Using Shepard's lemma on the price index, country $j$ 's demand for each variety can be written as follows:

$$
x_{i j}=p_{i j}^{-\sigma} E_{j} G_{j}^{\sigma-1}
$$

We assume that all varieties have the same producer price $\left(p_{i}\right)$ and that the sales of industrial goods by country $i$ to country $j$ are subject to Samuelson's iceberg transaction costs. These delivery costs are composed of two elements: the between countries transaction cost in international markets $\left(T_{i j s}\right)$, and the internal cost of getting the product to and from the border in countries $i$ and $j\left(t_{i}\right.$ and $\left.t_{j}\right)$. The final price ( $\left.p_{i j}\right)$ for any industrial product is thus composed of this producer price and all costs supported to deliver the product to market $j$ :

$$
p_{i j}=p_{i} t_{i} T_{i j} t_{j}
$$

The value of country $i$ 's exports to country $\mathrm{j}$ is therefore:

$$
n_{i} p_{i} x_{i j}=n_{i}\left(p_{i} t_{i}\right)^{1-\sigma} T_{i j}^{1-\sigma} E_{j}\left(G_{j} / t_{j}\right)^{\sigma-1}
$$


This equation facilitates the breakdown of all bilateral trade flows into the exporter's characteristics - country $i$ supply capacity: $S C_{i}=n_{i}\left(p_{i} t_{i}\right)^{1-\sigma}$, the importer's characteristics — country $j$ market absorptive capacity: $A_{j}=E_{j}\left(G_{j} / t_{j}\right)^{\sigma-1}$ - and the bilateral transaction cost between $i$ and $j\left(T_{i j}^{1-\sigma}\right)$. The supply capacity of the exporting country is the product of the number of varieties produced by the country — referred also as the country size — and its price competitiveness - which depends on the producer price and the internal transaction cost. On the other hand, the market absorptive capacity is a function of the importer's total expenditure, its internal transaction cost, and its consumer price index.

Consequently, the gravity equation that we will estimate is from the following relation:

$$
n_{i} p_{i} x_{i j}=S C_{i} T_{i j}^{1-\sigma} A_{j}
$$

Country $i$ 's total value of exports to all destinations $\left(V_{i}\right)$ can then be decomposed between its supply capacity and its foreign market access as follows:

$$
V_{i}=n_{i} p_{i} \sum_{j \neq i} x_{i j}=S C_{i} \sum_{j \neq i} T_{i j}^{1-\sigma} A_{j}=S C_{i} \cdot M_{i}
$$

where $M_{i}=\sum_{j \neq i} T_{i j}^{1-\sigma} A_{j}$ is the foreign market access of country $i$.

\section{Appendix 2: Our Country Sample and Database}

Table A1: Regional groupings

\begin{tabular}{|c|c|c|c|c|c|c|}
\hline \multirow{4}{*}{$\begin{array}{c}\text { Sub-Saharan } \\
\text { Africa }\end{array}$} & Angola & Benin & Burkina Faso & Burundi & Cameroon & Cape Verde \\
\cline { 2 - 7 } & Central African Rep. & Chad & Congo & Congo (D R) & Côte d'Ivoire & Djibouti \\
\cline { 2 - 7 } & Ethiopia & Gabon & Gambia & Ghana & Guinea & Guinea-Bissau \\
\cline { 2 - 7 } & Kenya & Madagascar & Malawi & Mali & Mauritania & Mauritius \\
\cline { 2 - 7 } & Mozambique & Niger & Nigeria & Rwanda & Senegal & Seychelles \\
\cline { 2 - 7 } & Sierra Leone & Somalia & Sudan & Togo & Uganda & Tanzania (U. R.) \\
\hline \multirow{3}{*}{$\begin{array}{c}\text { Developing } \\
\text { Asia }\end{array}$} & Zambia & Zimbabwe & & & & \\
\cline { 2 - 7 } & Indonesia & Lao People's DR & Malaysia & Maldives & Nepal & Pakistan \\
\cline { 2 - 7 } & Philippines & Sri Lanka & Thailand & Viet Nam & & \\
\hline
\end{tabular}

\section{Data sources:}

- Data on bilateral trade flows are from the UN COMTRADE database. Data on US GDP deflator, GDP (constant price 1990), and Population are from the UN Common database. 
- Data on geographical distance and border are from the CEPII: http://www.cepii.fr/anglaisgraph/bdd/gravity.htm

- The proportion of paved roads as a percentage of total roads comes from the World Development Indicators (2008). The indicators related to trading across borders are provided online by the World Bank: http://doingbusiness.org/

- Characteristics of institutional quality are from the Heritage Foundation. They can be downloaded from: http://www.heritage.org

1. Trade Freedom is a composite measure of the absence of tariff (T) and non-tariff barriers (NTB) that affect imports and exports of goods and services.

Trade Freedom $\left(T F_{i}\right)$ for a given country $\mathrm{i}$ is $T F_{i}=\frac{T_{\max }-T_{i}}{T_{\max }-T_{\min }}-N T B$

where $T_{\max }$ and $T_{\min }$ are the upper and lower bounds for tariff rates, and $T_{i}$ represents the weighted average tariff rate in country $i$. The minimum tariff is naturally zero, and the upper bound was set at 50 percent.

2. Freedom from Corruption is based on quantitative data that assess the perception of corruption in the business environment, including levels of governmental legal, judicial, and administrative corruption. It relies on Transparency International's Corruption Perceptions Index (CPI), which measures the level of corruption for a set of countries. 


\section{Appendix 3: Country Sources of Export Growth}

Panel 1: Sub-Saharan African countries

\begin{tabular}{|c|c|c|c|c|c|c|c|c|c|c|c|c|}
\hline \multirow{2}{*}{ Country } & \multicolumn{4}{|c|}{ Exports } & \multicolumn{4}{|c|}{ Foreign Market Access } & \multicolumn{4}{|c|}{ Supply Capacing } \\
\hline & $\begin{array}{l}92 / 94- \\
95 / 97\end{array}$ & $\begin{array}{c}95 / 97- \\
98 / 00\end{array}$ & $\begin{array}{l}98 / 00- \\
01 / 03\end{array}$ & $\begin{array}{c}01 / 03- \\
04 / 06\end{array}$ & $\begin{array}{l}92 / 94- \\
95 / 97\end{array}$ & $\begin{array}{c}95 / 97- \\
98 / 00\end{array}$ & $\begin{array}{c}98 / 00- \\
01 / 03\end{array}$ & $\begin{array}{c}01 / 03- \\
04 / 06\end{array}$ & $\begin{array}{l}92 / 94- \\
95 / 97\end{array}$ & $\begin{array}{l}95 / 97- \\
98 / 00\end{array}$ & $\begin{array}{c}98 / 00- \\
01 / 03\end{array}$ & $\begin{array}{l}01 / 03- \\
04 / 06\end{array}$ \\
\hline Angola & 20 & -46 & 45 & 52 & -36 & -12 & -16 & 14 & 87 & -38 & 73 & 33 \\
\hline Benin & 88 & 26 & 25 & -75 & 21 & 36 & 30 & -66 & 56 & -8 & -4 & -25 \\
\hline Burkina Faso & 162 & 24 & -31 & -16 & -20 & -17 & -17 & 13 & 228 & 49 & -18 & -25 \\
\hline Burundi & 12 & -45 & -24 & 99 & -34 & -13 & -16 & 17 & 68 & -36 & -9 & 70 \\
\hline Cameroon & 317 & -31 & 11 & 69 & -28 & -10 & -10 & -3 & 480 & -24 & 23 & 74 \\
\hline Cape Verde & 41 & -32 & -37 & 42 & -23 & -16 & -20 & 15 & 84 & -19 & -21 & 23 \\
\hline Central Afr Rep. & 51 & -35 & -20 & -13 & -30 & -15 & -16 & 13 & 117 & -24 & -4 & -23 \\
\hline Chad & 32 & -8 & -23 & 24 & -25 & -15 & -14 & 4 & 76 & 8 & -10 & 19 \\
\hline Congo & 189 & -9 & 23 & 59 & 39 & -40 & -9 & 2 & 108 & 52 & 36 & 56 \\
\hline Congo (D R) & 321 & -72 & -32 & 22 & 112 & -47 & -20 & 14 & 99 & -48 & -15 & 7 \\
\hline Côte d'Ivoire & 886 & 19 & -33 & 58 & -23 & -13 & -18 & 14 & 1187 & 37 & -19 & 40 \\
\hline Djibouti & -13 & -17 & -9 & 73 & -32 & -13 & -14 & 20 & 28 & -5 & 6 & 44 \\
\hline Ethiopia & 180 & -24 & 8 & 125 & -32 & -14 & -14 & 16 & 310 & -12 & 25 & 94 \\
\hline Gabon & 14 & -13 & -1 & 125 & -30 & -14 & -16 & 12 & 63 & 1 & 17 & 101 \\
\hline Gambia & 92 & -27 & -23 & 31 & -18 & -14 & -19 & 25 & 133 & -14 & -5 & 5 \\
\hline Ghana & 127 & 2 & -17 & 70 & -20 & -16 & -13 & 7 & 184 & 23 & -5 & 60 \\
\hline Guinea & 172 & -9 & -8 & -12 & -24 & -15 & -18 & 17 & 260 & 6 & 12 & -25 \\
\hline Guinea-Bissau & 8 & -41 & -4 & -9 & -20 & -15 & -19 & 15 & 35 & -30 & 19 & -21 \\
\hline Kenya & -1 & -16 & 89 & 134 & -34 & -13 & -15 & 18 & 50 & -3 & 122 & 99 \\
\hline Madagascar & -5 & -7 & 0 & 16 & -42 & -10 & -13 & 17 & 63 & 3 & 15 & -1 \\
\hline Malawi & 126 & 4 & -28 & 26 & -39 & -11 & -14 & 16 & 269 & 17 & -16 & 8 \\
\hline Mali & 117 & 32 & 8 & 52 & -22 & -17 & -18 & 13 & 177 & 58 & 31 & 35 \\
\hline Mauritania & 268 & -10 & -8 & 14 & -19 & -17 & -19 & 17 & 356 & 8 & 15 & -3 \\
\hline Mauritius & 20 & -9 & 8 & 90 & -43 & -9 & -12 & 18 & 109 & 0 & 23 & 61 \\
\hline Mozambique & -4 & 11 & 50 & 62 & -41 & -11 & -14 & 17 & 63 & 24 & 75 & 39 \\
\hline Niger & 152 & -20 & -1 & 72 & -20 & -13 & -11 & -4 & 216 & -8 & 11 & 80 \\
\hline Nigeria & 417 & 14 & -45 & -8 & -15 & -21 & -14 & 10 & 512 & 45 & -36 & -16 \\
\hline Rwanda & -2 & -11 & -20 & 86 & -32 & -15 & -16 & 17 & 44 & 4 & -5 & 59 \\
\hline
\end{tabular}




\begin{tabular}{|l|c|c|c|c|c|c|c|c|c|c|c|c|}
\hline Senegal & -19 & -8 & -22 & 179 & -21 & -17 & -20 & 14 & 2 & 11 & -3 & 144 \\
\hline Seychelles & -2 & 35 & 36 & 118 & -39 & -10 & -12 & 19 & 62 & 51 & 55 & 83 \\
\hline Sierra Leone & 12 & -39 & 38 & 40 & -24 & -15 & -19 & 11 & 47 & -28 & 70 & 26 \\
\hline Somalia & -18 & -17 & 5 & 1 & -35 & -12 & -11 & 19 & 27 & -6 & 18 & -15 \\
\hline Sudan & 110 & -12 & 2 & -11 & -26 & -17 & -16 & 17 & 186 & 6 & 21 & -24 \\
\hline Togo & 139 & 29 & 5 & -44 & -4 & -13 & -13 & 5 & 150 & 49 & 20 & -46 \\
\hline Uganda & 123 & 26 & -11 & 54 & -32 & -13 & -10 & 16 & 230 & 44 & 0 & 32 \\
\hline Tanzania & 134 & 93 & 13 & 1 & -36 & -11 & -10 & 18 & 264 & 118 & 26 & -14 \\
\hline Zambia & 27 & 35 & -41 & 30 & -35 & -15 & -14 & 16 & 97 & 59 & -31 & 12 \\
\hline Zimbabwe & -41 & -25 & -38 & -19 & -39 & -10 & -14 & 16 & -3 & -16 & -28 & -30 \\
\hline Sub-Saharan & $\mathbf{7 9}$ & $\mathbf{1}$ & $\mathbf{- 1 5}$ & $\mathbf{5 0}$ & $\mathbf{- 2 0}$ & $\mathbf{- 1 5}$ & $\mathbf{- 1 2}$ & $\mathbf{4}$ & $\mathbf{1 1 7}$ & $\mathbf{1 5}$ & $\mathbf{2}$ & $\mathbf{3 6}$ \\
\hline
\end{tabular}

Panel 2: Developing Asian countries

\begin{tabular}{|l|c|c|c|c|c|c|c|c|c|c|c|c|}
\hline & \multicolumn{5}{|c|}{ Exports } & \multicolumn{5}{c|}{ FMA } & \multicolumn{4}{c|}{ SC } \\
\cline { 2 - 15 } \multicolumn{1}{c|}{ Countries } & $\begin{array}{c}92 / 94- \\
95 / 97\end{array}$ & $\begin{array}{c}95 / 97- \\
98 / 00\end{array}$ & $\begin{array}{c}98 / 00- \\
01 / 03\end{array}$ & $\begin{array}{c}01 / 03- \\
04 / 06\end{array}$ & $\begin{array}{c}92 / 94- \\
95 / 97\end{array}$ & $\begin{array}{c}95 / 97- \\
98 / 00\end{array}$ & $\begin{array}{c}98 / 00- \\
01 / 03\end{array}$ & $\begin{array}{c}01 / 03- \\
04 / 06\end{array}$ & $\begin{array}{c}92 / 94- \\
95 / 97\end{array}$ & $\begin{array}{c}95 / 97- \\
98 / 00\end{array}$ & $\begin{array}{c}98 / 00- \\
01 / 03\end{array}$ & $\begin{array}{c}01 / 03- \\
04 / 06\end{array}$ \\
\hline Bangladesh & 32 & -5 & 57 & 166 & -11 & -10 & 25 & 95 & 49 & 5 & 26 & 37 \\
\hline Bhutan & 41 & -46 & 83 & 103 & -1 & -6 & 45 & 125 & 42 & -42 & 27 & -10 \\
\hline Brunei D. & 73 & -17 & 23 & 5 & -16 & -12 & -12 & 14 & 106 & -5 & 39 & -8 \\
\hline Cambodia & 412 & 19 & 45 & 70 & 144 & -31 & -26 & 33 & 110 & 73 & 97 & 28 \\
\hline China & 26 & -1 & 61 & 237 & -10 & -23 & 4 & 36 & 40 & 28 & 55 & 147 \\
\hline India & 77 & -1 & 47 & 240 & -14 & -7 & 15 & 87 & 107 & 7 & 28 & 81 \\
\hline Indonesia & 339 & 88 & -19 & 52 & -16 & -8 & -16 & 12 & 423 & 105 & -3 & 36 \\
\hline Lao P D R & 464 & -26 & -2 & 72 & 140 & -30 & -16 & 62 & 135 & 6 & 17 & 7 \\
\hline Malaysia & 382 & 31 & -15 & 30 & 126 & 30 & -25 & -24 & 114 & 1 & 14 & 71 \\
\hline Maldives & 3 & -20 & 28 & 45 & -37 & -10 & -9 & 21 & 62 & -11 & 41 & 19 \\
\hline Nepal & 77 & -4 & 45 & 241 & 13 & -6 & 54 & 136 & 56 & 1 & -6 & 44 \\
\hline Pakistan & 128 & -17 & 71 & 323 & 17 & -7 & 53 & 137 & 96 & -10 & 12 & 78 \\
\hline Philippines & 86 & 9 & 55 & 114 & -27 & -16 & -5 & 19 & 155 & 30 & 62 & 80 \\
\hline Sri Lanka & -65 & 165 & 22 & 34 & -34 & -11 & -8 & 22 & -47 & 198 & 32 & 10 \\
\hline Thailand & 47 & 0 & -8 & 121 & -17 & -12 & -10 & 21 & 76 & 13 & 2 & 83 \\
\hline Viet Nam & 811 & 182 & 177 & 349 & -8 & -11 & 23 & 105 & 892 & 216 & 126 & 119 \\
\hline Developing Asia & $\mathbf{8 2}$ & $\mathbf{1 3}$ & $\mathbf{2 2}$ & $\mathbf{1 7 3}$ & $\mathbf{3 2}$ & $\mathbf{- 1 3}$ & $\mathbf{- 1}$ & $\mathbf{6 3}$ & $\mathbf{7 2}$ & $\mathbf{2 6}$ & $\mathbf{3 3}$ & $\mathbf{1 1 4}$ \\
\hline
\end{tabular}

